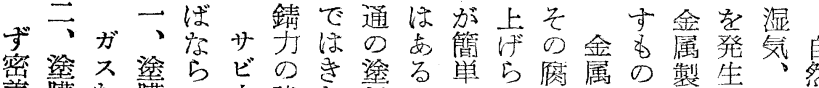

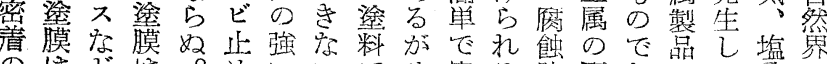

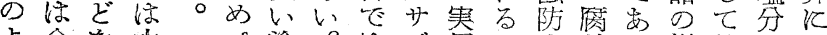

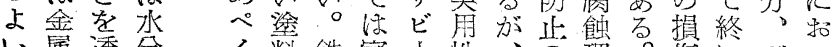
い属透分不料完止性、釷理。傷飞ガい この瀜りンを材全め方他一論将破スて

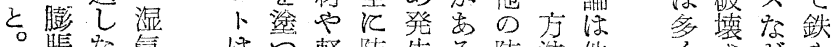
は整防生方防法他々管どや

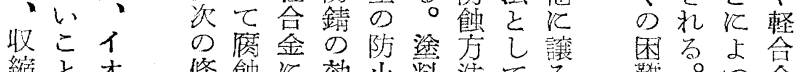

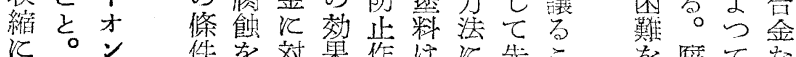

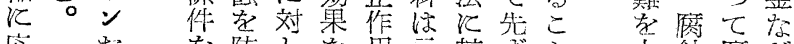

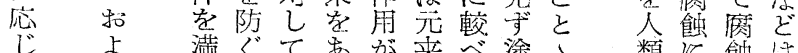

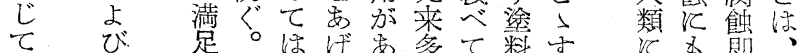

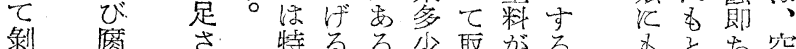

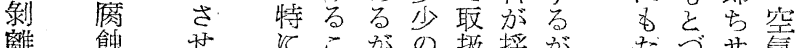

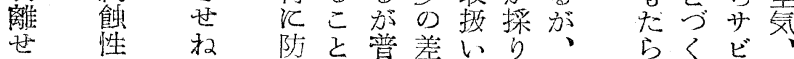

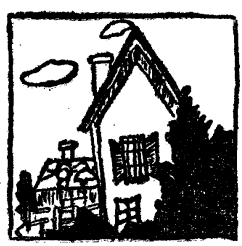

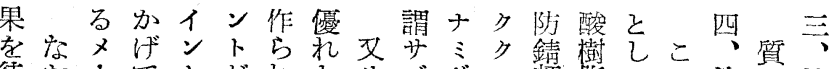

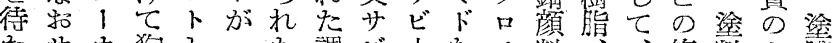
たサカ狗と航調ビ止なメ料台、條料よ膜 将 1 因称般赤合止めど、とビボ件にいの ば止のを劣褐へめ下が、し二イを使こ形

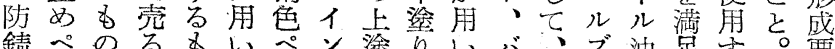
錶ぺのるる る

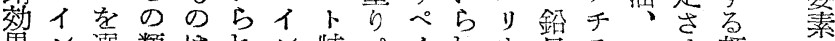
果ン選類はれン特ぺイれウ独ラフ退顔は

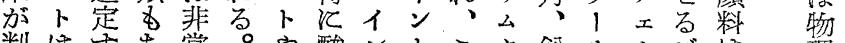
判は尔常。や酸シトこ方鉛儿, ビは埋 定長べるに市ア华卜が扎口粉な1飞防的 乙期きか多販儿鉄と作らメ年ルク蝕和

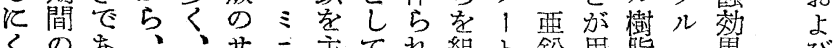

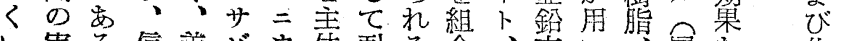

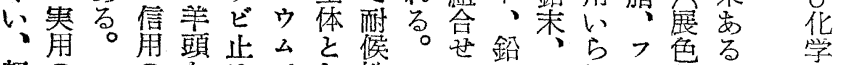

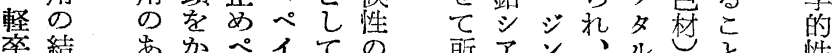

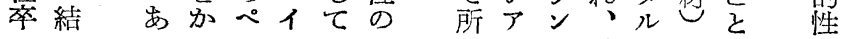

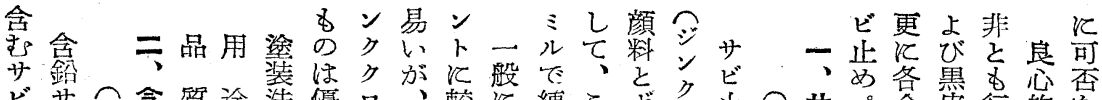

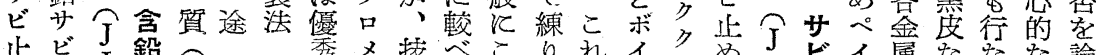
止ビ I 鉛第鉄刷な1秀メ挤べこ

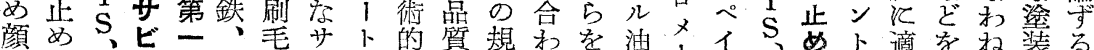

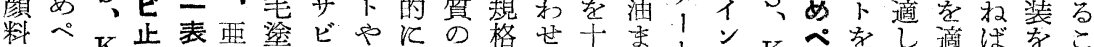

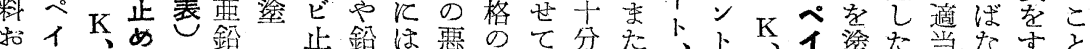

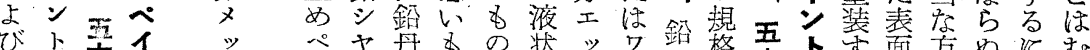

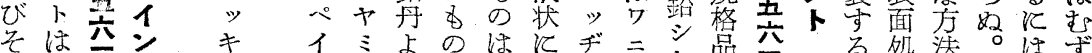

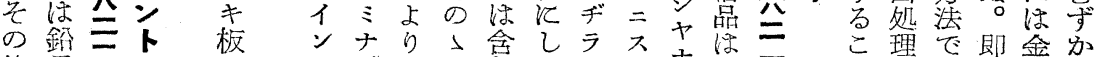

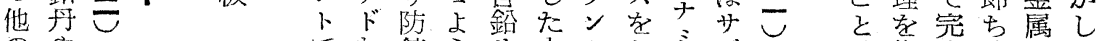

の

顔 唯

料 酸

と 化

ボ鈆

1孝
でな錆方サすすナ物志ビ あぞ性飞ビの 1 も卡 るをの閏步でやな步山 使良違め䊦品原导顔 心㭁方，料体顔
が施全油のい

望记脂前

しかいサ理

いら去ビ索 
現場パンフレットNo.16

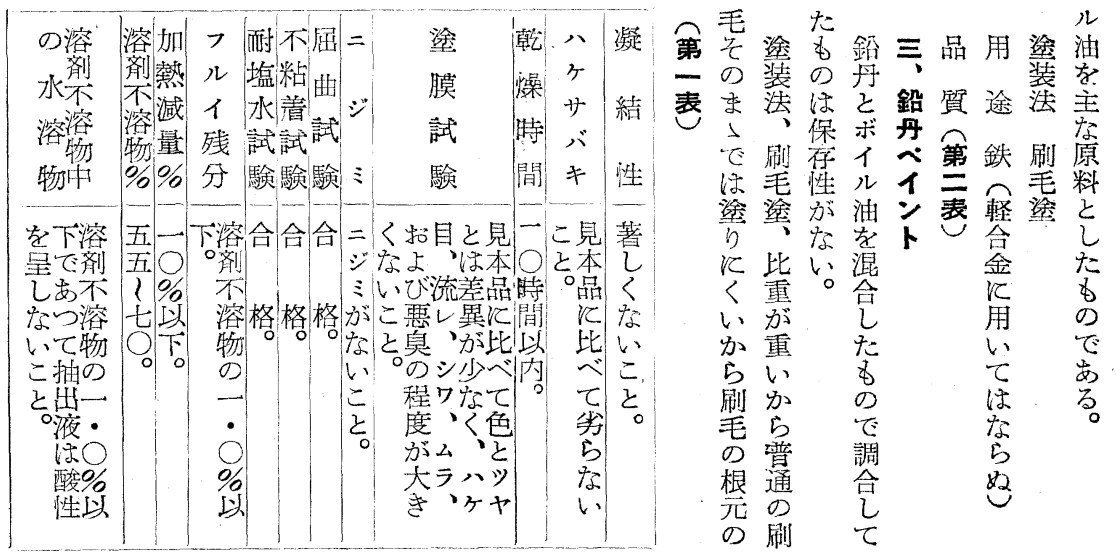

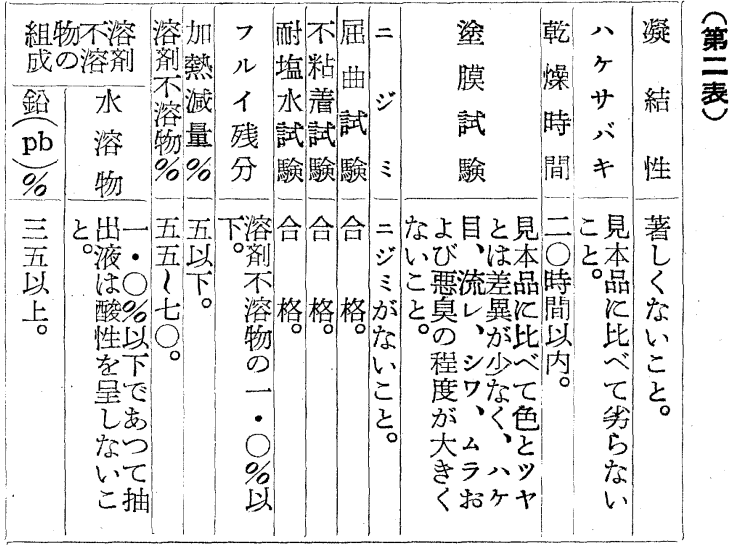

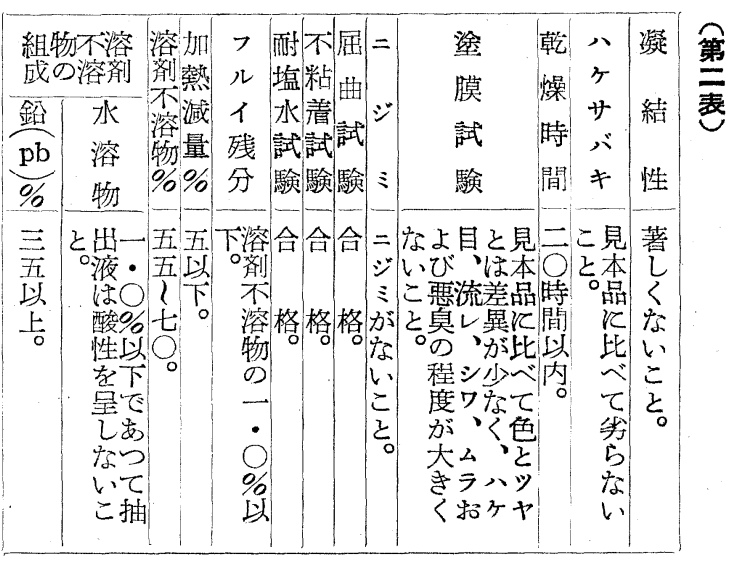

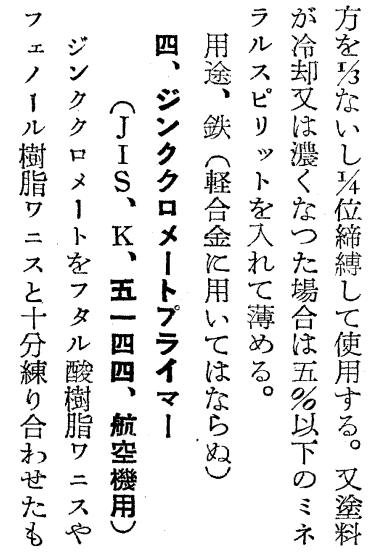

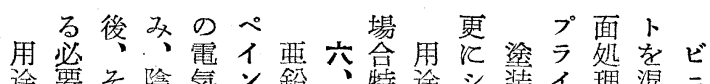
途要々除気ン鉛、特途装イ理混二 鉄市被性学の顔

万覆的的特料 帶。住被反長と

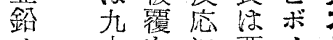
×士学に要イ 吾鉄よ鉛ル 板 首麺強鉄ら

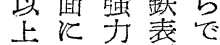
分な面き 要へ防江て 鉊る銹鍍い 老江作金尚 含は用さ。 有乾をれこ 寸燥営その
ジに上さ法マと和ル ク淦金 1二でビたチ理

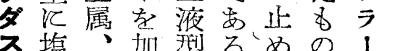

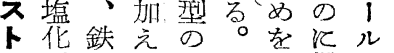
ヘ ビ ンル鉛撆は 卜䒺メ文原 塗兴液 料示吹江 学板付燐 用今䤰 酸 い船学を る舶る 加

\section{同燐 の}

時酸溶

等 液

行壱 5 加 シ 面元》 処金》 理属口 兼のメ 用表 1
五鉄角要途加架洷 面 ラウ鋊光方法乾 処イオメアて。懆 理マシッ儿窑又刷方 育 1 בキミ装吹毛早 用、プ板二梦付塗 フェラロウる整の防 厶。の場 錆 $\begin{array}{lll}\text { チ } & \text { 合 場合能 } \\ \text { ク } & \text { 菙 } & \text { 合約良 }\end{array}$

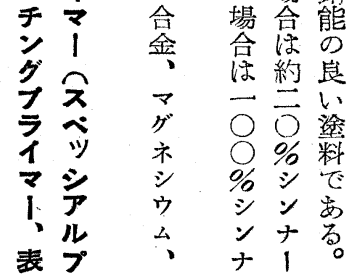

